\title{
Performance Evaluation of 'Saradhaa' Hybrid Solar Box Cooker
}

\author{
Jeyagowri, R. and Gnanasakthi Jagadeesan
}

\begin{abstract}
Saradhaa' hybrid solar box cooker operating in dual mode of energy namely solar and electricity (HSBC) was designed and its efficiency was assessed in terms of time taken to cook selected food items using different methods of cooking, different modes of operation namely solar, electrical and dual mode and compared with the cooker ' $D$ ' (based on the results on available six solar box cookers in the market). The different cooking methods revealed that baking cake and biscuit took a maximum time $(90 \mathrm{~min})$ followed by boiling Bengal gram whole and cow pea (45 to $55 \mathrm{~min}$ ). Roasting groundnut and green gram dhal required 40 to $45 \mathrm{~min}$. Steaming of Idli and string hoppers (Idiappam) was possible in 20 to $25 \mathrm{~min}$. Time taken to prepare a family meal in different modes of operation revealed that the cumulative time taken to cook a family meal of $777 \mathrm{~g}$ of foods loaded together was found to be $2 \mathrm{hr}-30 \mathrm{~min}$ in solar mode on a bright sunny day of $350 \mathrm{C}$ of ambient temperature and $909.81 \mathrm{w} / \mathrm{m} 2$ of solar insolation. When the foods were loaded together with the heater setting at $1200 \mathrm{C}$ for indoor cooking, dhal got cooked in 70 min followed by vegetable at $105 \mathrm{~min}$ and the complete cooking including rice was over by $130 \mathrm{~min}$. The electricity consumption was estimated as $867 \mathrm{w} / \mathrm{hr}$. The cooking experiment in dual mode of solar and electricity indicated that the cumulative time required to prepare a meal was $2 \mathrm{hr}-25 \mathrm{~min}$.. It is hoped that this new model, which can be utilised in all seasons would find new vistas in the field of solar cooking technology.
\end{abstract}

Keywords - Performance evaluation, hybrid, solar box cooker, solar radiation, ambient temperature, food temperature.

\section{INTRODUCTION}

The developing countries today consume 30 per cent of the world's total energy in domestic sector and will be 50 per cent by 2020 and probably 70 per cent in 2100 . The energy requirement in domestic sector is 40 to 50 per cent of the total energy requirements in India today. Moreover the energy needs in the domestic sector are increasing annually at the rate of 8.1 per cent. An analysis of household energy consumption pattern reveals that the major use is for heating and cooking. Owing to the need for tapping solar energy especially for household cooking, and non-availability of low cost, compact, efficient and versatile cooker to be used during sunny and nonsunny hours of the day, a device for all days use in a year was developed. A novel 'Saradhaa' hybrid solar box cooker comparatively which conserves less time, portable, durable, easy to use and maintain, at an affordable cost were the significant features incorporated in the newly developed

Department of Resource Management, Avinashilingam Institute for Home Science and Higher Education for Women, Coimbatore - 641043 cooker and its performance was analyzed with the following objectives:

- Assess the time taken to cook selected food items using different methods of cooking in the newly developed 'Saradhaa' hybrid cooker.

- Conduct cooking performance tests for the newly developed 'Saradhaa' hybrid cooker in different modes such as solar, electrical and dual modes of solar and electrical energy.

\section{MATERIALS AND METHODS}

\section{A. Assessing the Performance Ability of the Newly} Developed Hybrid Solar Box Cooker

A newly fabricated 'Saradhaa' hybrid solar box cooker was assessed for its performance ability. 'Saradhaa' cooker, a viable smart home technology was hybridized with electricity, for cooking food during non-sunshine hours and cloudy days suitable for an average family of four members. It was designed and fabricated with the best performed materials based on the test results and also from the study of existing available similar types of solar box cookers (Figure 1). This hybrid solar box cooker was made of Fibre Reinforced Plastic (FRP) outer body with the dimensions of $56.5 \mathrm{~cm} \times 38.5 \mathrm{~cm} \times 18.5 \mathrm{~cm}$ and the copper tray for inner box having the floor area of $0.1584 \mathrm{~m}^{2}$. The cover plate consisted of two toughened glasses of $3 \mathrm{~mm}$ thickness with a spacing of $10 \mathrm{~mm}$ in between them. The mirror was used as reflector having an area of $0.1664 \mathrm{~m}^{2}$. White rock wool and yellow resin bonded glass wool of $40 \mathrm{~mm}$ thickness was packed as an insulation material. The electrical backup of 400 wattage heating element and thermostat control were fitted in the solar cooker. The cost of the cooker is Rs '3000/- which can be procured at an affordable cost. These features made the cooker look unique and highly efficient compared to other cookers.

\section{B. Conducting Cooking Performance Test}

The cooking performance test was carried out with the following aspects:

\section{Cooking Methods}

The different methods of cooking namely, boiling, steaming, roasting and baking were tried out for the feasibility of cooking in 'Saradhaa' hybrid solar box cooker. Cooking experiment was carried out by selecting two foods of $100 \mathrm{~g}$ each under each method of cooking. The time taken to cook each food item under different cooking methods was recorded. 
During the experimental days, the various factors such as ambient temperature, tray temperature, food temperature, solar radiation and sunshine hours were recorded.

\section{Cooking in different Modes}

The cooking experiment was conducted in 'Saradhaa' HSBC in solar mode and indoor electrical mode.

\section{Outdoor Solar Mode}

The foods namely rice, dhal and vegetable $100 \mathrm{~g}$ each with standardized quantity of water were taken in a stainless steel copper bottom black painted container. The cooker was kept in the sunlight at $10 \mathrm{a} . \mathrm{m}$. in the morning and oriented towards the South East direction. After preheating for half an hour, each food item was cooked separately in solar mode. The time taken to cook each food item was noted. The ambient temperature and solar radiation were also recorded. Likewise, all the food items were taken in three containers and loaded at a time in the cooker and allowed to cook. The cumulative times taken to cook all the three food items were recorded along with ambient temperature and solar radiation.

\section{Indoor Electrical Mode}

Hundred grams of the same foods were cooked in Saradhaa in indoor mode by setting the heater element at $1000^{\circ} \mathrm{C}$ and $1200^{\circ} \mathrm{C}$. The time taken to cook each food item in two different thermostat settings and the cooked food temperature were recorded. The energy consumed for cooking in terms of w/hr was assessed. Likewise all the three foods in three containers were cooked at a time. The cumulative time taken to cook the foods was recorded. The electrical energy consumption was also observed.

\section{Cooking a Family Meal}

A family meal containing rice, dhal and vegetable were cooked at a time in solar cooker. The quantity of foods required for a meal to a family of four members (two adults and two school going children 12 years old boy and a 9 years old girl) was estimated as per the recommended Indian
Council of Medical Research (ICMR)(Table.1).

TABLE I: QUANTITY OF FoOdS REQUIRED For A FAMILY MEAL

\begin{tabular}{|c|c|c|c|c|c|}
\hline \multirow{2}{*}{$\begin{array}{c}\text { Food } \\
\text { stuff }\end{array}$} & \multicolumn{4}{|c|}{ Quantity of food (g) } & Total \\
\cline { 2 - 5 } & $\begin{array}{c}\text { Adult } \\
\text { man }\end{array}$ & $\begin{array}{c}\text { Adult } \\
\text { woman }\end{array}$ & \multicolumn{2}{|c|}{$\begin{array}{c}\text { School going } \\
\text { children }\end{array}$} & $\begin{array}{c}\text { quantity } \\
\text { (g) }\end{array}$ \\
\cline { 4 - 5 } & & & Boy & Girl & \\
\hline Rice & 156 & 123 & 111 & 95 & 485 \\
Dhal & 13 & 13 & 20 & 20 & 66 \\
Vegetab & 70 & 63 & 50 & 43 & 226 \\
le & & & & & \\
\hline Total & $\mathbf{2 3 9}$ & $\mathbf{1 9 9}$ & $\mathbf{1 8 1}$ & $\mathbf{1 5 8}$ & $\mathbf{7 7 7}$ \\
\hline
\end{tabular}

The foods such as rice, dhal and vegetable were cooked in solar mode, indoor electrical mode and outdoor dual mode of solar and electrical energy in three separate containers. The heater setting was kept at $120 \mathrm{oC}$ during the electrical mode of operation. The cumulative time taken to cook foods for a meal was recorded for each mode of operation as per the cooking procedure adopted earlier.

\section{RESULTS AND DISCUSSION}

\section{A. Cooking Performance of Hybrid Solar Box Cooker}

The cooking test consisted of cooking foods in different methods, cooking in solar and indoor electrical mode and preparing family meal under three modes of operation.

\section{Cooking Methods}

The different cooking methods such as boiling, steaming, roasting and baking were carried out in 'Saradhaa' HSBC with the selected two foods of $100 \mathrm{~g}$ each under each method of cooking. The time taken to cook the selected foods under different methods of cooking, the temperature of cooked food and the corresponding solar energy parameters are presented in Table 2:

TABLE II: Time TAKen to CoOK the Selected Foods by DifFerent Methods

\begin{tabular}{|c|c|c|c|c|c|c|c|}
\hline $\begin{array}{l}\text { Cooking } \\
\text { method }\end{array}$ & Foodstuff & $\begin{array}{l}\text { Time } \\
\text { taken }\end{array}$ & \begin{tabular}{|c|} 
Ambient \\
temperature \\
$\left({ }^{0} \mathrm{c}\right)$
\end{tabular} & $\begin{array}{c}\text { Tray } \\
\text { temperature } \\
\left({ }^{0} \mathrm{c}\right)\end{array}$ & $\begin{array}{c}\text { Food } \\
\text { temperature } \\
\left({ }^{0} \mathrm{c}\right)\end{array}$ & $\begin{array}{c}\text { Solar radiation } \\
\left(\text { cal s/cm } / \mathrm{cm}^{2} / \text { day }\right)\end{array}$ & $\begin{array}{l}\text { Sunshine } \\
\text { hours }\end{array}$ \\
\hline \multirow[t]{2}{*}{ Boling } & $\begin{array}{l}\text { Bengal } \\
\text { gram whole }\end{array}$ & 45 & 33 & 112 & 97 & 492.8 & 11.0 \\
\hline & Cow pea & 55 & 32 & 107 & 94 & 462.0 & 10.8 \\
\hline \multirow[t]{2}{*}{ Steaming } & Idli & 20 & 32 & 109 & 92 & 485.1 & 11.2 \\
\hline & $\begin{array}{c}\text { String } \\
\text { hoppers } \\
\text { (idiappam) }\end{array}$ & 25 & 32 & 111 & 97 & 462.0 & 10.8 \\
\hline \multirow{2}{*}{ Roasting } & & 40 & 32 & 110 & 87 & 462.0 & 10.8 \\
\hline & $\begin{array}{c}\text { groundnut } \\
\text { green gram } \\
\text { dhal }\end{array}$ & 45 & 32 & 107 & 99 & 446.6 & 10.5 \\
\hline \multirow{2}{*}{ Baking } & & 90 & 35 & 112 & 98 & 477.4 & 10.8 \\
\hline & $\begin{array}{c}\text { Cake } \\
\text { Biscuit }\end{array}$ & 95 & 35 & 109 & 92 & 462.0 & 10.5 \\
\hline
\end{tabular}

It was observed that baking cake and biscuit took a maximum time (90 to $95 \mathrm{~min}$ ) followed by boiling Bengal gram whole and cow pea (45 to $55 \mathrm{~min}$ ). Roasting groundnut and green gram dhal required 40 to $45 \mathrm{~min}$. Steaming of Idli 
and String hoppers (idiappam) was possible in 20 to $25 \mathrm{~min}$. During the experimental period, the ambient temperature, solar radiation and sunshine hours ranged from $300^{\circ} \mathrm{C}$ to $350^{\circ} \mathrm{C}$, 446.6 to $492.8 \mathrm{cals} / \mathrm{cm} 2 /$ day and 10.5 to 11.2 hours per day respectively. The tray temperature during cooking ranged from $1070^{\circ} \mathrm{C}$ to $1120^{\circ} \mathrm{C}$ while the cooked food temperature was $870^{\circ} \mathrm{C}$ to $990^{\circ} \mathrm{C}$, showing the effective heat inside the cooking tray.

\section{B. Cooking in Different Modes of Operation}

\section{Solar Mode}

Table 3 shows the time taken to cook foods in 'Saradhaa' hybrid solar box cooker by solar mode when the solar radiation was above $430 \mathrm{cals} / \mathrm{cm} 2 /$ day and the ambient temperature was in the range of $330^{\circ} \mathrm{C}$ to $350^{\circ} \mathrm{C}$.

TABLE III: TIME TAKEN TO COOK FoOdS IN 'SARADHAA' COOKER By SOLAR MODE

\begin{tabular}{|c|c|c|c|c|c|c|}
\hline Foodstuff & $\begin{array}{c}\text { Quantity } \\
\text { (g) }\end{array}$ & $\begin{array}{l}\text { Time } \\
\text { taken } \\
\text { (min) }\end{array}$ & $\begin{array}{c}\text { Tray } \\
\text { temperature } \\
\left({ }^{\circ} \mathrm{C}\right)\end{array}$ & $\begin{array}{c}\text { Food } \\
\text { temperature } \\
\left({ }^{\circ} \mathrm{C}\right)\end{array}$ & $\begin{array}{c}\text { Ambient } \\
\text { temperature } \\
\left({ }^{\circ} \mathrm{C}\right)\end{array}$ & $\begin{array}{l}\text { Solar radiation } \\
\text { (cals/cm/day) }\end{array}$ \\
\hline $\begin{array}{l}\text { Loaded individually } \\
\text { Rice, parboiled } \\
\text { Red gram dhal } \\
\text { Vegetable - French } \\
\text { beans } \\
\text { Loaded together } \\
\text { Rice, dhal and } \\
\text { Vegetable }\end{array}$ & $\begin{array}{l}100 \\
100 \\
100\end{array}$ & $\begin{array}{l}50 \\
45 \\
35\end{array}$ & $\begin{array}{l}145 \\
140 \\
140\end{array}$ & $\begin{array}{l}99 \\
99 \\
99\end{array}$ & $\begin{array}{l}33 \\
34 \\
34\end{array}$ & $\begin{array}{l}462.0 \\
477.4 \\
475.6\end{array}$ \\
\hline
\end{tabular}

When foods were cooked individually by keeping one container at a time, rice took the maximum of $50 \mathrm{~min}$ followed by dhal (45 min) and vegetable ( $35 \mathrm{~min}$ ) during which the tray temperature was recorded between $1400^{\circ} \mathrm{C}$ and $1450^{\circ} \mathrm{C}$ and the food temperature was $990^{\circ} \mathrm{C}$. When all the three foods were loaded in the cooker in three separate containers with the total weight of $300 \mathrm{~g}$, the time taken to cook all the three foods was found to be 75 minutes only. The cooked food temperature was recorded as $990^{\circ} \mathrm{C}$ while the tray temperature was $1350^{\circ} \mathrm{C}$. It was inferred from the findings that a time saving of 42 per cent could be accrued when the foods were cooked together instead of individually.

\section{Electrical Mode}

The cooking experiment was also conducted in 'Saradhaa' hybrid box cooker at indoor electrical mode with 400 watts capacity of heating element by setting the thermostat control at $1000^{\circ} \mathrm{C}$ and $1200^{\circ} \mathrm{C}$ level for cooking rice, dhal and vegetable, individually and all the foods loaded together. The observations recorded are shown in Table4:

TABLE IV: TIME TAKEN TO COOK FOODS IN 'SARADHAA' COOKER BY ELECTRICAL MODE

\begin{tabular}{|c|c|c|c|c|c|c|}
\hline Foodstuff & $\begin{array}{c}\text { Quantity } \\
\text { (g) }\end{array}$ & $\begin{array}{c}\text { Heater } \\
\text { setting } \\
\left({ }^{\circ} \mathrm{C}\right)\end{array}$ & $\begin{array}{l}\text { Time } \\
\text { taken } \\
(\min )\end{array}$ & $\begin{array}{l}\text { Food } \\
\text { temperature } \\
\text { ('C) }\end{array}$ & $\begin{array}{c}\text { Energy } \\
\text { consumed } \\
(\mathrm{w} / \mathrm{hr})\end{array}$ & $\begin{array}{l}\text { Heater } \\
\text { capacity } \\
\text { (w) }\end{array}$ \\
\hline $\begin{array}{l}\text { Loaded individually } \\
\text { Rice, parboiled } \\
\text { Red gram dhal } \\
\text { Vegetable - French bean } \\
\text { Loaded together } \\
\text { Rice, dhal and vegetable }\end{array}$ & $\begin{array}{l}100 \\
100 \\
100 \\
300\end{array}$ & $\begin{array}{l}100 \\
120 \\
100 \\
120 \\
100 \\
120 \\
100 \\
120\end{array}$ & $\begin{array}{l}50 \\
40 \\
40 \\
35 \\
30 \\
25 \\
100 \\
85\end{array}$ & $\begin{array}{l}98 \\
99 \\
96 \\
99 \\
89 \\
92 \\
96 \\
97\end{array}$ & $\begin{array}{l}333 \\
267 \\
267 \\
233 \\
200 \\
167 \\
667 \\
567\end{array}$ & 400 \\
\hline
\end{tabular}

The time taken to cook rice in electrical mode with heater setting at $1000^{\circ} \mathrm{C}$ was found to be $50 \mathrm{~min}$ followed by dhal (40 min) and vegetable (30 min) with an electrical consumption of $333 \mathrm{w} / \mathrm{hr}, 267 \mathrm{w} / \mathrm{hr}$ and $200 \mathrm{w} / \mathrm{hr}$ respectively. When foods were cooked at $1200^{\circ} \mathrm{C}$ heater setting, the time taken was lesser by $10 \mathrm{~min}$ in the case of rice and five minutes for dhal and vegetable with the lesser consumption of electricity (34 to $66 \mathrm{w} / \mathrm{hr}$ ). When rice, dhal and vegetable were loaded at a time in three separate containers at $1000^{\circ} \mathrm{C}$, the cooking time was recorded as $100 \mathrm{~min}$ with $667 \mathrm{w} / \mathrm{hr}$ energy consumption while it was $85 \mathrm{~min}$ with the lesser wattage of $567 \mathrm{w} / \mathrm{hr}$ at $1200^{\circ} \mathrm{C}$ heater setting. When the foods were loaded together in electrical mode, 15 to 17 per cent of time and electrical energy could be saved on comparison with individual loading.

\section{Cooking a Family Meal in Different Modes of Operation}

A meal comprising of rice $(485 \mathrm{~g})$, dhal $(66 \mathrm{~g})$ and vegetable (226g) was prepared for an average family of four members as per ICMR recommended allowances in 'Saradhaa' hybrid solar box cooker in solar, electrical and dual modes of operation. The time taken to cook a family meal in different modes of operation is given in Table 5 .

TABLE V: Time TAKEN to PREPARE A FAMILY MEAL IN DIFFERENT MODES

\begin{tabular}{|c|c|c|c|c|c|c|c|c|c|c|}
\hline \multicolumn{11}{|c|}{ OF OPERATION } \\
\hline $\begin{array}{l}\text { Mode of } \\
\text { operation }\end{array}$ & Foodstuff & $\begin{array}{c}\text { Quantity } \\
\text { (g) }\end{array}$ & $\begin{array}{l}\text { Heater } \\
\text { setting } \\
\left({ }^{\circ} \mathrm{C}\right)\end{array}$ & \begin{tabular}{|c} 
Tray \\
temper- \\
ature \\
$\left({ }^{\circ} \mathrm{C}\right)$ \\
\end{tabular} & $\begin{array}{l}\text { Time } \\
\text { taken } \\
\text { (min) }\end{array}$ & $\begin{array}{l}\text { Food } \\
\text { tempe- } \\
\text { rature } \\
\left({ }^{\circ} \mathrm{C}\right)\end{array}$ & $\begin{array}{c}\text { Ambient } \\
\text { tempera } \\
\text { ture } \\
\left({ }^{\circ} \mathrm{C}\right)\end{array}$ & $\begin{array}{l}\text { Solar } \\
\text { insolation } \\
\left(\mathrm{w}^{2} \mathrm{~m}^{2}\right)\end{array}$ & $\begin{array}{c}\text { Energy } \\
\text { consumed } \\
\text { (w/hr) }\end{array}$ & $\begin{array}{l}\text { Heater } \\
\text { capacity } \\
\text { (w) }\end{array}$ \\
\hline Solar & $\begin{array}{l}\text { Rice, dhal } \\
\text { vegetable }\end{array}$ & 777 & & 130 & 150 & 99 & 35 & 909.81 & - & - \\
\hline Electrical & $\begin{array}{l}\text { Dhal } \\
\text { Vegetable } \\
\text { Rice }\end{array}$ & $\begin{array}{l}66 \\
226 \\
485\end{array}$ & 120 & $\begin{array}{l}135 \\
148 \\
140\end{array}$ & $\begin{array}{l}70 \\
105 \\
130\end{array}$ & $\begin{array}{l}98 \\
98 \\
98\end{array}$ & $\dot{.}$ & . & $\begin{array}{l}467 \\
700 \\
867\end{array}$ & 400 \\
\hline Dual & $\begin{array}{l}\text { Dhal } \\
\text { Vegetable } \\
\text { Rice }\end{array}$ & $\begin{array}{l}66 \\
226 \\
485\end{array}$ & 120 & 140 & $\begin{array}{c}35 \\
85 \\
145\end{array}$ & $\begin{array}{l}98 \\
98 \\
98\end{array}$ & 32.5 & 569.62 & 266 & 400 \\
\hline
\end{tabular}

\section{CONCLUSION}

Newly developed Saradhaa cooker had lot of unique features such as compact in size, portable in nature with affordable price of Rs`3000/- and could be used for a family of four members and a family meal can be cooked at a time in this cooker in solar, electrical and in dual modes. Two castor wheels attached in the front side bottom made the cooker movable easily. Two knobs placed at rear side bottom helped the cooker to be stable at the time of use. Different methods of cooking were possible in this cooker. The high thermal efficiency achieved in the developed 'Saradhaa' HSBC model would help in reducing the drudgery in cooking and saves the homemakers time and energy. It is hoped that this new model, which can be utilized in all seasons would find new vistas in the field of solar cooking technology.

\section{REFERENCES}

[1] Tata Energy Research Institute, 2000, Tata energy data and directory year book, Tata energy research institute, New Delhi, 2000, 1-2.

[2] Balakrishnan, L., Solar cookers - use and technology-AIWC experience, proceedings of the third international conference on solar cookers - use and technology, Avinashilingam Deemed University, Coimbatore, 1998, 171-172. 
[3] Varadappan, S. Contributions of AIWC solar cooking", Proceedings of the third international conference on solar cookers - use and technology, Avinashilingam Deemed University, Coimbatore, 1998, 38-41.

[4] Indian Council of Medical Research (ICMR), 2007, Dietary Guidelines for Indians- A Manual, National Institute of Nutrition, Hyderabad, 7274.

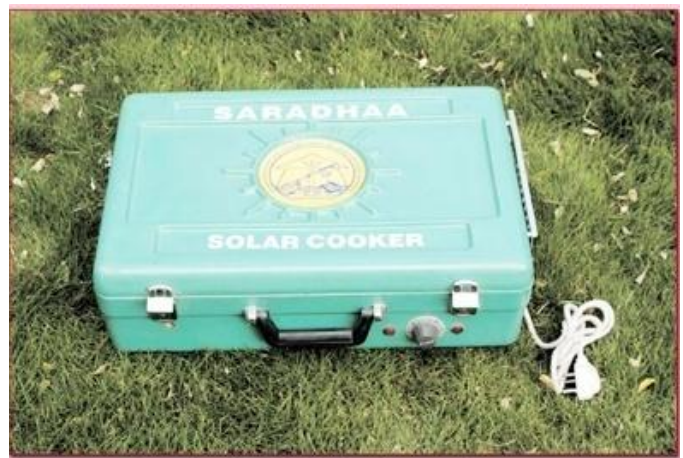

'Saradhaa' hybrid solar box cooker

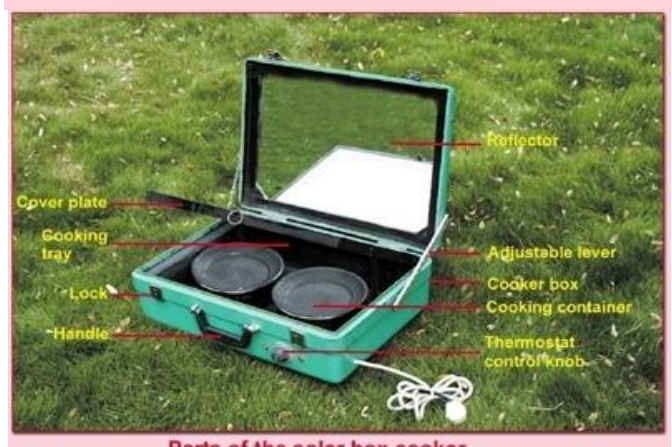

Parts of the solar box cooker

Fig. 1: 'Saradha' Hybrid Solar Box Cooker 